\title{
Dimensions underlying legislator support for tobacco control policies
}

\author{
N A de Guia, J E Cohen, M J Ashley, R Ferrence, J Rehm, D T Studlar, D Northrup
}

Tobacco Control 2003;12:133-139

See end of article for authors' affiliations

Correspondence to: Nicole de Guia, Canadian Institute for Health Information, 90 Eglinton Ave. East Suite 300, Toronto, Ontario M4P 2Y3, Canada; ndeguia@cihi.ca

Received 17 February 2002. Accepted 28 February 2003

\begin{abstract}
Objective: To propose and test a new classification system for characterising legislator support for various tobacco control policies.

Design: Cross sectional study.

Subjects: Federal and provincial legislators in Canada serving as of October 1996 who participated in the Canadian Legislator Study ( $\mathrm{n}=553$; response rate 54\%).

Main outcome measures: A three factor model (Voters, Tobacco industry, Other interest groups) that assigns nine tobacco control policies according to legislators' hypothesised perceptions of which group is more directly affected by these policies.

Results: Based on confirmatory factor analysis, the proposed model had an acceptable fit and showed construct validity. Multivariate analysis indicated that three of the predictors (believing that the government has a role in health promotion, being a non-smoker, and knowledge that there are more tobacco than alcohol caused deaths) were associated with all three factor scales. Several variables were associated with two of the three scales. Some were unique to each scale.

Conclusions: Based on our analyses, legislator support for tobacco control policies can be grouped according to our a priori factor model. The information gained from this work can help advocates understand how legislators think about different types of tobacco control policies. This could lead to the development of more effective advocacy strategies.
\end{abstract}

$\mathrm{S}$ udying legislators' support for tobacco control policies is important because legislators are key players in the policymaking process. Legislators' attitudes toward specific tobacco control policies have been documented in Canada, ${ }^{1-3}$ the USA, ${ }^{4-7}$ and the Netherlands. ${ }^{8}$ However, no attempt has yet been made to investigate whether legislators are consistent in their views about various tobacco control policies-that is, the extent to which support for one policy is associated with support for another type of policy, yet, at the same time, independent from support for other tobacco control policies. Such information would be useful for advocates because it would help them anticipate legislator support for a particular tobacco control policy. It might also suggest salient approaches to introducing tobacco control strategies in order to maximise legislator support.

Grouping tobacco control policies requires that they share a common, underlying factor. A few studies have reported common factors underlying the tobacco control attitudes of the general public ${ }^{9-11}$ and students, ${ }^{12}$ primarily for the development of survey instruments. For instance, in 1994 Velicer et al developed a smoking policy instrument based on five factors or constructs: ( 1 ) advertising and promotion; (2) public education; (3) laws and penalties; (4) taxes and fees; and (5) restrictions on smoking. ${ }^{11}$ This survey instrument was utilised to compare support for tobacco control policies in selected populations in six countries. ${ }^{9}$ Although such factors could be relevant to the attitudes of legislators, characteristics of legislators as a political elite ${ }^{1314}$ have led us to investigate other possible structures.

In this study, we propose and test a factor structure hypothesised to underlie legislator support for tobacco control using data from a survey of Canadian federal and provincial legislators. This factor structure is based on three theoretically derived classifications of tobacco control policies according to groups that legislators might believe would be more directly affected by these policies. In a secondary analysis, we investigate the predictors that differentiate among and are shared by the proposed factors.
The first classification is based on the fact that legislators rely on voters for their election and re-election. We postulate that legislators think similarly about policies that can more directly affect the voting public. Indeed, models of legislator voting behaviour in the USA show that legislators are sensitised to whether issues are controversial to voters. ${ }^{15}{ }^{16}$ Even in Canada, where a party based system of government exists, legislators are sensitive to the views of their constituents. ${ }^{17}$ Studies have shown that policies that directly affect smokers, such as cigarette tax increases and smoking restrictions in public places, are important to the general population. Public attitudes toward these policies diverge considerably depending on the respondent's self interest in these issues, as measured by smoking status and degree of bother by smoke. ${ }^{18}{ }^{19}$ In a study of legislators from North Carolina, Texas, and Vermont, constituent pressure was perceived to be the strongest social influence on voting intentions regarding cigarette tax increases. ${ }^{20}$

Second, legislators may think similarly about tobacco control policies that more directly affect the tobacco industry. Since legislators enact policy, they are exposed to intense lobbying efforts by the tobacco industry in both Canada ${ }^{21}$ and the USA. ${ }^{22}{ }^{23}$ Substantial numbers of legislators in the USA receive campaign contributions from the tobacco industry, and these contributions arguably have influenced legislators' policy decisions. ${ }^{24-27}$ Although a similar degree of contribution activity has not been found in Canada, it is likely that substantial lobbying occurs through other means. ${ }^{28}$ While any effective tobacco control policy should impact on the industry in some way, there are some tobacco control policies that more directly target the tobacco industry (for example, suing tobacco companies to recoup health care costs); therefore, we hypothesise that legislators would think similarly about tobacco industry related policies.

Third, legislators may also think similarly about tobacco control policies that more directly affect interest groups other than the tobacco industry. For example, a ban on event sponsorship of sports or cultural events by the tobacco industry 
Table 1 Factor assignment of nine tobacco policy items*

\begin{tabular}{|c|c|c|}
\hline Factor & Item label & Item description \\
\hline $\begin{array}{l}\text { More directly affects voters } \\
\text { (Voters) }\end{array}$ & $\begin{array}{l}\text { Price increase } † \\
\text { Work ban } \ddagger \\
\text { Car bant }\end{array}$ & $\begin{array}{l}\text { Cigarette prices should be increased by } \$ 0.50 / \$ 1.00 \\
\text { Smoking should be banned in workplaces } \\
\text { Should be law that parents cannot smoke in car with } \\
\text { children }\end{array}$ \\
\hline $\begin{array}{l}\text { More directly affects the } \\
\text { tobacco industry } \\
\text { (Tobacco industry) }\end{array}$ & $\begin{array}{l}\text { Liability for } \\
\text { suffering } \ddagger \\
\text { Recoup health costs } \ddagger \\
\text { Plain packaging } \dagger\end{array}$ & $\begin{array}{l}\text { Tobacco companies should be liable for smokers' } \\
\text { suffering } \\
\text { Government should sue tobacco companies for health } \\
\text { care costs } \\
\text { Plain packaging should be mandatory }\end{array}$ \\
\hline $\begin{array}{l}\text { More directly affects other } \\
\text { interest groups in community } \\
\text { (Other interest groups) }\end{array}$ & $\begin{array}{l}\text { Sponsorship ban } \dagger \\
\text { Ads regulated } \ddagger \\
\text { Sales regulated } \ddagger\end{array}$ & $\begin{array}{l}\text { Event sponsorship should be banned } \\
\text { Government should regulate tobacco advertising } \\
\text { Cigarettes should be sold in stores with more than } \\
\text { minimal government regulation }\end{array}$ \\
\hline
\end{tabular}

would more directly affect arts and sporting groups who may rely heavily on tobacco industry funding. Since these groups lobby legislators, legislators may be particularly sensitised to their needs and concerns.

We hypothesise, then, that legislators group tobacco control policies in terms of three underlying factors: (1) policies that more directly affect the voting public (for example, increasing cigarette taxes); (2) policies that more directly affect the tobacco industry (for example, government suits against tobacco companies to recover health care costs); and (3) policies that more directly affect other interest groups in the community (for example, banning tobacco sponsorship of cultural events). We empirically test these hypotheses and investigate the properties of the resulting support scales.

\section{METHODS}

\section{Sample}

Data for this analysis were obtained from the Canadian Legislator Study. ${ }^{29}$ All Canadian federal $(\mathrm{n}=295)$ and provincial/ territorial $(n=760)$ legislators serving as of October, 1996 were eligible. Data were collected using structured computer assisted telephone interviews conducted in English and French by the Institute for Social Research at York University $(\mathrm{n}=553$; overall response rate $54 \%)$. Ten of the 13 jurisdictions had response rates of at least $60 \%$; participation was lowest among legislators at the federal level (40\%) and in the province of Quebec (27\%). Response rates did not vary by age, sex, educational attainment, having an academic degree, or the presence of tobacco farms, tobacco processing or manufacturing plants, or tobacco company head offices in a legislator's electoral district. However, current or former ministers or party leaders, legislators with a longer length of service, and those who were lawyers were less likely to respond $(\mathrm{p}<0.05)$.

\section{Variables}

The survey covered a wide variety of health topics with a focus on attitudes toward current tobacco control issues and the extent of contact between legislators and lobbying groups.

*The exception was the item on mandatory plain packaging that was posed only to legislators who thought this was within the government's jurisdiction $(n=365)$.
Nine tobacco policy items asked of all the respondents were included in the following analyses. *All policy areas investigated are within the constitutional powers of both provincial/ territorial and federal legislators. Using the described a priori factor structure, each of the policy items was assigned to one of the three factors (table 1).

\section{Statistical analyses}

Items were recoded into dichotomous ("indicated support" versus "did not indicate support") or trichotomous categories ("strongly support", "somewhat support", "did not indicate support") and treated as ordinal variables, with a higher value representing more support for the specific measure. "Don't know" and "refused" responses were classified as "did not indicate support". Confirmatory factor analysis using this a priori classification structure was conducted using LISREL 8.3. ${ }^{31}{ }^{32}$ Confirmatory factor analysis allows the statistical testing of a theoretically derived factor structure. The factor structure consists of variables grouped into coherent subsets (factors). Underlying processes that create the correlations among the variables are reflected in the factors. A factor, or latent variable, represents the underlying dimension that unifies the variables that load on it. As the variable items in this study had ordinal scaling, statistical analysis based on Pearson correlations would lead to biased results. Therefore, we used a LISREL analysis based on polyserial and polychoric correlation coefficients to obtain unbiased results with regards to the underlying factor structure. The results of a confirmatory factor analysis can be depicted in a path diagram. ${ }^{33} \dagger$

To make use of the full sample of respondents, respondents who indicated they did not think cigarette packaging was within the government's jurisdiction were classified as "did not indicate support" (for plain packaging of cigarettes), a conservative imputation.

Because the confirmatory factor analysis supported the existence of the three hypothesised categories (see fig 1 and

†Rectangles represent measured variables, while circles represent factors (latent variables). Parameter estimates, or loadings, are shown above the arrows from the factors to the measured variables. The higher the loading ( 1 = perfect correlation), the stronger the relation between the measured variable and the factor. The respective error variances - that is, the variances in the measures not explained by the latent variables-are shown above the arrow to the left of each measured variable. 
results below), scale values for the three factors (Voters, Tobacco industry, Other interest groups) were computed using loadings as weights. Higher scale values indicate stronger support for the cluster of underlying measures. Items were standardised with a mean of 0 and a variance of 1 to form the scales because response categories varied across items. In this way, all items were given the same potential weight within a factor. Construct validity of each scale was investigated by examining scale means by both smoking status and political party. Non-smokers were expected to show more support than smokers, as reported previously among studies of the general public ${ }^{34-37}$ and one study of US legislators. ${ }^{38}$ Support for tobacco control policies was expected to decrease from left leaning to right leaning party affiliation. Of the major political parties in Canada, the New Democratic Party is considered to have the most left leaning views; the Parti Québécois is also on the left; the Liberal Party is about centre; the Progressive Conservative party is considered right of the Liberals, and the Reform Party is considered right of the Progressive Conservatives. ${ }^{39-41}$ At the time of the Canadian Legislator Study, Liberals governed at the federal level, and in Newfoundland, Nova Scotia, New Brunswick and Prince Edward Island. The Progressive Conservative party formed the government in Ontario, Manitoba, and Alberta, and the New Democratic Party governed in Saskatchewan, British Columbia, and the Yukon. The Parti Québécois governed Quebec. Legislators in the Northwest Territories do not have party affiliations.

Bivariate relations between each of the three scales and a number of explanatory variables were examined using linear regression. Explanatory variables were: political factors (party affiliation, membership in a governing party, position as cabinet minister, and three measures of political ideology personal characteristics (age, sex, and educational attainment); tobacco experiences (smoking status and family death caused by smoking); knowledge about tobacco's harmful effects (second hand smoke, tobacco addiction, the higher number of tobacco caused deaths compared to those caused by alcohol); and interest group saliency (tobacco industry presence in electoral district, perception of whether the tobacco industry provided jobs in the electoral district, receptivity to tobacco related contact from non-profit health lobbyists and from medical association lobbyists).

Items retained in the final multivariate model were those that had a significant association $(\mathrm{p}<0.05)$ with at least one of the scales in the bivariate analysis; two additional items were also dropped.§ All scale analyses were conducted using the statistical program Stata. ${ }^{42}$

\section{RESULTS}

\section{Model fit}

A path diagram of this factor structure is shown in fig 1. Factor loadings ranged from 0.57 (cigarettes should be banned in workplaces) to 0.97 (government should sue companies for

\#First, legislators located their political views on a 10 point left-righ bipolar scale, with 1 indicating far left and 10 indicating far right. Twenty five per cent of respondents were not asked this item because it was added to the survey after interviews began. Second, legislators were asked whether they thought the level of government regulation of the private sector was too little, too much, or about right. Third, a Health Promotion Ideology Scale (HPIS) was created based on five items on the duty of the state to promote healthy lifestyles: (1) should the government have a major role in promoting healthy lifestyles or is this the responsibility of the individual? (2) does the government have a major responsibility, some responsibility or no responsibility for encouraging healthy eating habits? (3) for preventing alcohol abuse? and (4) for encouraging people to be physically active? and (5) would the cost of health care be lower if more money were put into health promotion programmes? The five items were standardised and summed to form the HPIS, which had a reliability coefficient of 0.80 . health care costs); all nine items had loadings greater than 0.50 . The adjusted goodness-of-fit index was 0.97 , and the root mean square error of approximation was $0.098 \quad(90 \%$ confidence interval (CI) 0.083 to 0.110 ), implying good to excellent fit of the model. ${ }^{43}$ The correlations were 0.83 between Voters and Tobacco industry, 0.87 between Voters and Other interest groups, and 0.89 between Tobacco industry and Other interest groups.

\section{Scale reliability}

The Voters scale showed moderate reliability and was within acceptable range for a Gaussian distribution $(\alpha=0.45$; skew $=0.20$; kurtosis $=2.03$ ). The Tobacco industry scale showed substantial reliability and was also within acceptable range for a Gaussian distribution $(\alpha=0.69$; skew $=0.68$; kurtosis $=2.10$ ). The Other interest groups scale showed moderate reliability and was within acceptable range for a Gaussian distribution $(\alpha=0.47$; $\quad$ skew $=-0.36$; $\quad$ kurtosis $=2.27$ ). Pearson's correlation between the Voters and Tobacco industry scales was 0.43 ; it was 0.37 between the Voters and Other interest groups scales, and 0.45 between the Tobacco industry and Other interest groups scales.

\section{Construct validity}

For all three scales, mean support was higher among non-smokers compared to smokers (table 2). For the Tobacco industry and Other interest groups scales, mean support generally decreased across political parties from left to right, confirming the construct validity of these scales.

\section{Bivariate analyses}

In the bivariate linear regression models, a number of variables were associated $(\mathrm{p}<0.05)$ with one or more of the three scales (data not shown). Political party was an important predictor for all three scales. New Democrats were more supportive of all three groups of tobacco policies compared to all parties combined, whereas Progressive Conservatives were less supportive. The following variables were also associated $(\mathrm{p}<0.05)$ with more support for all three scales: having a higher score on the health promotion ideology scale; not believing there is too much private sector regulation by the government; being a non-smoker; having a family member who died from smoking; knowing second hand smoke can cause cancer; believing most smokers are addicted; knowing that, overall, tobacco causes more deaths than does alcohol; and being receptive to more tobacco related contact by medical association lobbyists.

Two variables were associated ( $p<0.05$ ) with more support for two of the three scales: placement toward the left of the left-right bipolar ideology scale (for Tobacco industry and Other interest groups), and being receptive to more tobacco related contact by non-profit health lobbyists (for Voters and Other interest groups). Three variables were associated $(p<0.05)$ with more support for only one of the three scales: being a government minister (for Other interest groups), being female (for Voters), and tobacco industry presence in the electoral district (for Voters).

\section{Multivariate analyses}

The final multivariate linear regression showed that several variables were independently associated $(p<0.05)$ with one or more of the three scales (table 3 ). Three variables were associated $(\mathrm{p}<0.05)$ with higher support for all three scales:

$\S$ The bipolar ideology scale was dropped to increase the sample size. Because the receptivity to contact by non-profit health lobbyists item was significantly correlated with the item regarding medical association lobbyists $(r=0.47)$, the former item was dropped. 


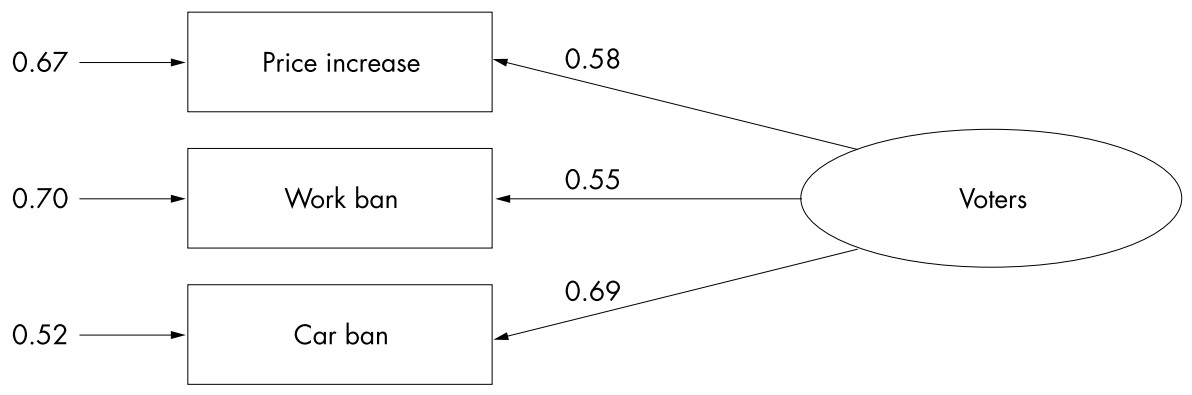

Figure 1 Path diagram for factor model.
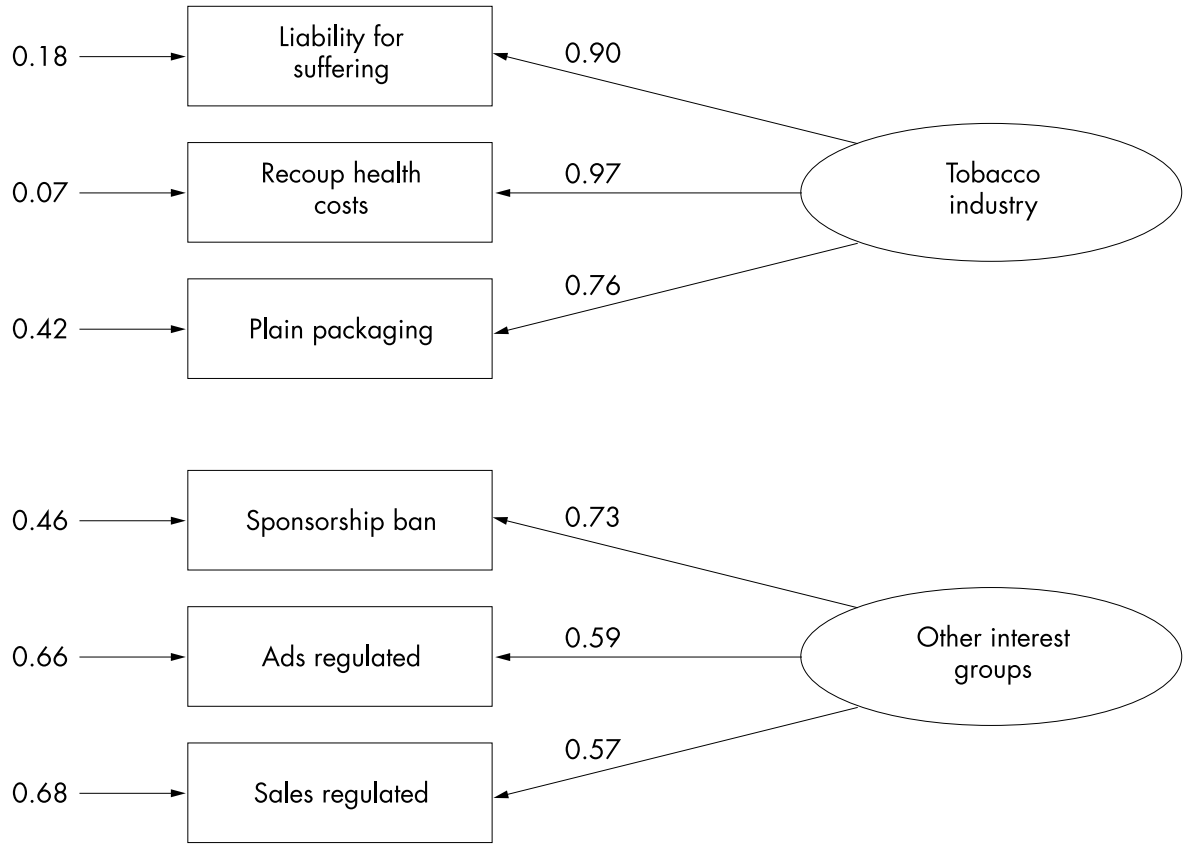

higher scores on the health promotion ideology scale (believing that the government has a role in health promotion); being a non-smoker; and knowledge that, overall, tobacco causes more deaths than alcohol.

Several variables were associated $(p<0.05)$ with two of the three scales. Political party was an important predictor for policies affecting the Tobacco industry and Other interest groups, but not for policies affecting Voters. Support was higher $(\mathrm{p}<0.01)$ among New Democratic party members compared to Liberal party members (reference group) for these scales and lower among Progressive Conservative party legislators compared to the Liberals for the Other interest groups scale. For both the Voters and Other interest groups scales, support was higher $(\mathrm{p}<0.05)$ among those who were receptive to more medical association contacts on tobacco related issues.

Some variables were unique predictors of one scale. For policies directly affecting voters, there was more support among government ministers, among legislators who did not think there was too much government regulation of the private sector, among female legislators, and among those who knew that second hand smoke can cause cancer $(p<0.05)$. For policies directly affecting other interest groups, more support was found among legislators who had a close friend or family member who died from a disease that might have been caused by smoking $(\mathrm{p}<0.05)$.

Table 2 Mean scale values by smoking status and political party $\dagger$

\begin{tabular}{|c|c|c|c|}
\hline & Voters & $\begin{array}{l}\text { Tobacco } \\
\text { industry }\end{array}$ & $\begin{array}{l}\text { Other interest } \\
\text { groups }\end{array}$ \\
\hline Smoking status & *** & ** & ** \\
\hline Smoker $(n=100)$ & -0.32 & -0.23 & -0.18 \\
\hline Non-smoker $(n=450)$ & 0.07 & 0.06 & 0.04 \\
\hline Political party & NS & $\star * *$ & $\star * *$ \\
\hline Reform $(n=40)$ & -0.03 & -0.28 & -0.37 \\
\hline Progressive Conservative ( $n=99$ ) & -0.14 & -0.24 & -0.34 \\
\hline Liberal $(n=275)$ & 0.00 & -0.01 & 0.03 \\
\hline New Democrat $(n=96)$ & 0.15 & 0.33 & 0.41 \\
\hline Other $(n=43) \ddagger$ & 0.00 & 0.18 & 0.03 \\
\hline
\end{tabular}

†Testing using one way analysis of variance (ANOVA)

Includes Bloc Québécois, Parti Québécois, Yukon Party, and Independents

NS, not significant at $\mathrm{p}=0.05 ;{ }^{*} \mathrm{p}<0.01 ;{ }^{* * *} \mathrm{p}<0.001$. 
Table 3 Multivariate associations between proposed tobacco control support scales and several explanatory variables; coefficients and $p$ values from multiple linear regressions

\begin{tabular}{|c|c|c|c|c|c|c|}
\hline \multirow[b]{2}{*}{ Independent variables } & \multicolumn{2}{|l|}{ Voters $†$} & \multicolumn{2}{|c|}{ Tobacco industry } & \multicolumn{2}{|c|}{ Other interest groups $\dagger$} \\
\hline & Coefficient & $\mathrm{p}$ Value & Coefficient & $\mathrm{p}$ Value & Coefficient & $\mathrm{p}$ Value \\
\hline \multicolumn{7}{|l|}{ Political factors } \\
\hline New Democratł & 0.01 & NS & 0.26 & ** & 0.31 & *** \\
\hline Progressive Conservative $\ddagger$ & 0.02 & NS & -0.11 & NS & -0.25 & ** \\
\hline Reform $\ddagger$ & 0.17 & NS & -0.05 & NS & -0.15 & NS \\
\hline Other party $\ddagger$ & 0.07 & NS & 0.29 & * & 0.08 & NS \\
\hline Government minister & 0.19 & * & 0.11 & NS & 0.14 & NS \\
\hline Health promotion ideology scale & 0.11 & ** & 0.19 & $* * *$ & 0.23 & $* * *$ \\
\hline Too much private sector regulation & -0.14 & * & -0.09 & NS & -0.03 & NS \\
\hline \multicolumn{7}{|l|}{ Personal characteristics } \\
\hline Sex $($ female $=1$, male $=0$ ) & 0.16 & * & -0.11 & NS & -0.05 & NS \\
\hline \multicolumn{7}{|l|}{ Tobacco experiences } \\
\hline Smoker & -0.28 & $* * *$ & -0.22 & * & -0.14 & * \\
\hline Family death from smoking & 0.06 & NS & 0.06 & NS & 0.12 & * \\
\hline \multicolumn{7}{|l|}{ Tobacco knowledge } \\
\hline Second hand smoke can cause cancer & 0.37 & *** & 0.07 & NS & 0.16 & NS \\
\hline Most smokers are addicted & 0.17 & NS & 0.15 & NS & 0.07 & NS \\
\hline More tobacco $v$ alcohol deaths & 0.17 & ** & 0.24 & $* * *$ & 0.15 & ** \\
\hline \multicolumn{7}{|l|}{ Interest group saliency } \\
\hline Tobacco industry presence & -0.17 & NS & -0.03 & NS & -0.06 & NS \\
\hline Receptive to more medical association contact & 0.12 & * & 0.07 & NS & 0.12 & * \\
\hline \multicolumn{7}{|c|}{$\begin{array}{l}\text { †For all regression analyses, } n=549 \text {. } \\
\text { †Compared to Liberals. } \\
\text { NS, not significant at } \mathrm{p}=0.05 ;{ }^{*} \mathrm{p}<0.05 ;{ }^{* *} \mathrm{p}<0.01 ;{ }^{* * *} \mathrm{p}<0.001 \text {. } \\
\text { The Liberal Party was the comparison category for the political party indicator variables because it is the largest group and also is considered a "centre" } \\
\text { party on the ideological spectrum. }\end{array}$} \\
\hline
\end{tabular}

\section{DISCUSSION}

Our primary analysis tests a model that describes how legislators may think about tobacco control policies. Our policy classification system is based on consideration of legislators' possible perceptions of groups who would be more directly affected by such policies. Confirmatory factor analysis supported our three theoretically derived categories.

Although our support scales show construct validity, the specific items used should not be used as stand alone survey instruments since the original survey instrument was not designed for scale development purposes. There are a limited number of items per scale, and for two of the three scales, the $\alpha$ reliability coefficients are lower than ideal (under 0.50 ). Validated survey items would be more appropriate to tap into the postulated factor structure.

Our postulated factor structure was empirically confirmed as a valid structure to describe legislators' support for tobacco control policies. Our analyses show that, at least at one point in time, there were common policy groupings for tobacco control measures among Canadian legislators from two different levels of government.

Three of the variables examined-the health promotion ideology scale, being a non-smoker, and knowledge that there are more tobacco caused deaths than alcohol caused deaths overall-were positively associated with all three scales. These findings give further credibility to the categorisation structure because it is likely that legislators who do not smoke, who believe the government has a role in health promotion, and who are aware of tobacco's public health impact would be more supportive of all tobacco control efforts. Moreover, the association between tobacco knowledge, smoking behaviour, and support for tobacco control policies has been shown previously in general population samples. ${ }^{34} 44$

Even in the multivariate analyses, political party was an important predictor for two of the three scales (Tobacco industry and Other interest groups). New Democrats, considered left leaning, were more supportive than Liberals, whereas
Progressive Conservatives, considered right leaning, were less supportive. Indeed, in other legislator studies, political ideology has been found to predict tobacco control support in the expected direction. ${ }^{6}{ }^{24} 25$ That the Progressive Conservatives were found to be less sympathetic than members of the Reform party (who are considered even more right leaning) was not an unexpected finding. Similar results from the same dataset have been reported and discussed in a previous paper. ${ }^{1}$

The information gained from this work can help advocates understand how legislators think about different types of tobacco control policies, which could lead to the development of more effective advocacy strategies. If it is known there is legislator support for a particular tobacco policy, these findings demonstrate that support is also present or can be gained for other related tobacco policies as categorised in this model.

Constructing effective policy frames may be one way to help advocates gain support for specific tobacco control policies. Research has shown that a strong relation exists between how a policy is framed or defined and the solutions developed in response to the problem. ${ }^{45}$ For example, Jacobson et al ${ }^{23}$ and Nathanson $^{46}$ have concluded that the manner in which the debate has been framed has influenced the strength of the tobacco control policies enacted. Although the tobacco industry is often portrayed as a corporate pariah in the press, ${ }^{47}$ some have argued that there remains a need for the tobacco control movement to develop a "consistent, powerful and compelling message" for the mass media that can effectively garner public and political support. ${ }^{48}$

Clearly, more studies are needed to determine what messages would be effective. For example, it might be useful to explore whether support for bans on smoking in workplaces arises from concerns about the general protection of workers, or from concerns about the specific effects of second hand smoke. Such information could suggest how the need for bans on smoking in other locations, such as restaurants, bars, and vehicles, could best be framed. 


\section{What this paper adds}

Legislator attitudes toward tobacco control policies have been documented in Canada, the USA, and the Netherlands. No previous study, to our knowledge, has investigated the dimensions underlying legislators' attitudes toward various tobacco control policies - that is, the extent to which support for one type of policy is associated with support for another type of policy, yet, at the same time, independent from support for other tobacco control policies.

This study provides a new method of grouping tobacco control policies, based on our perceptions of legislators' views of whether voters, the tobacco industry, or other interest groups would be more directly affected by specific policies. The information gained from this work can help advocates understand how legislators think about different types of tobacco control policies and help them anticipate legislator support for a particular tobacco control policy.

We hope that this research stimulates others to investigate common factors underlying legislator and public attitudes toward tobacco control. Because our model is based on the Canadian parliamentary system, in which party cohesion is a major characteristic, future research could attempt to replicate our factor structure among legislators in countries with less partisan legislative voting, such as the USA. If similar factors are found across time, space, and political systems, there would be a strong basis for developing effective frames of reference that could be used to influence legislators and potentially other key decision makers.

\section{ACKNOWLEDGEMENTS}

The authors would like to thank Ed Adlaf of the Centre for Addiction and Mental Health and Frank Ivis of the Canadian Institute for Health Information for their guidance and input. We also thank staff at the Institute for Social Research at York University in Toronto for contacting and interviewing the legislators. Dianne Alexander assisted in collecting additional legislator data from public sources. We would like to express our appreciation to all of the legislators who contributed their opinions, and to the former legislators who assisted in questionnaire development. These analyses were supported through grants from Health Canada's National Health Research and Development Program.

\section{Authors' affiliations}

*N A de Guia, †J E Cohen, †M J Ashley, $¥ R$ Ferrence, Ontario Tobacco Research Unit, Centre for Health Promotion, University of Toronto, Toronto, Ontario, Canada

§J Rehm, Department of Public Health Sciences, University of Toronto, Toronto, Ontario, Canada

D T Studlar, West Virginia University, Morgantown, USA

D Northrup, Institute for Social Research, York University, Toronto, Ontario, Canada

*Now with the Canadian Institute for Health Information, Toronto, Canada

†Also Department of Public Health Sciences, University of Toronto, Canada

$\ddagger$ Also Department of Public Health Sciences, University of Toronto, and Centre for Addiction and Mental Health, Toronto, Canada

$\S A$ lso Centre for Addiction and Mental Health, Toronto, Canada

\section{REFERENCES}

1 Cohen JE, de Guia NA, Ashley M, et al. Predictors of Canadian legislators' support for tobacco control policies. Soc Sci Med 2002;55:1069-76

2 Cohen JE. Ideology and Canadian legislators' support for tobacco control policies. Doctoral Dissertation. University of North Carolina at Chapel Hill, North Carolina, USA, 1999
3 de Guia NA, Cohen JE, Ashley MU, et al. How provincial and territorial legislators view tobacco and tobacco control: findings from a Canadian study. Chronic Diseases in Canada 1998;19:57-61.

4 Davis SK, Winkleby MA, Farquar JW. Increasing disparity in knowledge of cardiovascular disease risk factors and risk-reduction strategies by socioeconomic status: implications for policymakers. Am J Prev Med 1995;11:318-23.

5 Gifford R, Brindley MS. Attitudes of the Wisconsin State Legislature toward tobacco control policies. Wisconsin Med J 1994;93:582-4

6 Goldstein AO, Cohen JE, Flynn BS, et al. State legislators' attitudes and voting intentions toward tobacco control legislation. Am J Public Health 1997;87: $1197-200$

7 Hahn EJ, Toumey CP, Rayens MK, et al. Kentucky legislators' views on tobacco policy. Am J 'Prev Med 1999;16:81-8.

8 Hendriks VM, Garretsen HFL, van de Goor IAM. A "parliamentary inquiry" into alcohol and drugs: a survey of psychoactive substance use and gambling among members of the Dutch parliament. Substance Use \& Misuse 1997;32:679-97.

9 Laforge RG, Velicer WF, Levesque DA, et al. Measuring support for tobacco control policy in selected areas of six countries. Tobacco Control 1998;7:241-6.

10 Taylor SM, Ross NA, Goldsmith $\mathrm{CH}$, et al. Measuring attitudes towards smoking in the community intervention trial for smoking cessation (COMMIT). Health Educ Res 1998;13:123-32.

11 Velicer WF, Laforge RG, Levesque DA, et al. The development and initial validation of the smoking policy inventory. Tobacco Control 1994:3:347-55

12 Shore TH, Tashchian A, Adams JS. Development and validation of a scale measuring attitudes toward smoking. J Soc Psychol 2000;140:615-23

13 Putnam RD. The comparative study of political elites. Eaglewood Cliffs, New Jersey: Prentice-Hall, 1976

14 Studlar DT, Alexander DL, Cohen JE, et al. A social and political profile of Canadian legislators, 1996. Journal of Legislative Studies 2000;6:93-103.

15 Kingdon J. Models of legislative voting. Journal of Politics 1977;39:563-95.

16 Mayhew D. Congress: the electoral connection. New Haven: Yale University Press, 1974

17 Docherty D. Mr. Smith goes to Ottawa. Vancouver, BC: University of British Columbia Press, 1997

18 Green DP, Gerken AE. Self-interest and public opinion toward smoking restrictions and cigarette taxes. Public Opinion Quarterly 1989;53:1-16.

19 Dixon RD, Lowery RC, Levy DE, et al. Self-interest and public opinion toward smoking policies: a replication and extension. Public Opinion Quarterly 1991:55:241-54.

20 Flynn BS, Goldstein AO, Solomon L, et al. Predictors of state legislators' intentions to vote for cigarette tax increases. Prev Med 1998;27:157-65

21 Pross AP, Stewart IS. Breaking the habit: attentive publics and tobacco regulation. In: Phillips S, editor. How Ottawa spends, 1994-95. Ottawa, Ontario: Carleton University Press, 1994:129-64.

22 Glantz SA, Balbach ED. The tobacco wars: inside the California battles. Berkeley, California: University of California Press, 2000

23 Jacobson PD, Wasserman J, Raube K. The politics of antismoking legislation. Journal of Health Politics, Policy, and Law 1993;18:787819

24 Glantz SA, Begay ME. Tobacco industry campaign contributions are affecting tobacco control policymaking in California. JAMA 1994;272:1176-82.

25 Moore S, Wolfe SM, Lindes D, et al. Epidemiology of failed tobacco control legislation. JAMA 1994;272:1171-5.

26 Monardi F, Glantz SA. Are tobacco industry campaign contributions influencing state legislative behaviour? Am J Public Health 1998:88:918-23.

27 Wright JR. Tobacco industry PACs and the nation's health: a second opinion. In: Herrnson PS, Shailo RG, Wilcox C, eds. The interest group connection: electioneering, lobbying, and policymaking in Washington. Chatham, New Jersey: Chatham House, 1998:174-95.

28 Alexander DL, Cohen JE, Ferrence R, et al. Tobacco industry campaign contributions in Ontario, 1990-95. Can J Public Health 1997:88:230-1.

29 Ashley MJ, Ferrence R, Northrup D, et al. Survey of federal, provincia and territorial legislators regarding tobacco and tobacco control policies. Report prepared for Health Canada, National Health Research and Development Program Project No. 6606-5782-800. Toronto, Ontario: Ontario Tobacco Research Unit, 1997.

30 Northrup D. The Canadian Legislator Survey: a survey of federal, provincial, and territorial legislators regarding tobacco, tobacco control, and other health issues. Technical documentation. Toronto, Ontario: Institute for Social Research, York University, 1997

31 du Toit S, du Toit M, Jöreskog K, et al. Interactive LISREL: Scientific Software International, 1999

32 Jöreskog K, Sörbom D, du Toit S, et al. LISREL 8: new statistical features: Scientific Software International, 1999.

33 Tabachnick BG, Fidell LS. Using multivariate statistics, 3rd ed. Northridge, California: Harper Collins College Publishers, 1996.

34 Ashley MJ, Cohen J, Bull S, et al. Knowledge about tobacco and attitudes toward tobacco control: how different are smokers and nonsmokers? Can J Public Health 2000;91:376-80.

35 Ashley MJ, Bull SB, Pederson LL. Support among smokers and nonsmokers for restrictions on smoking. Am J Prev Med 1995;1 1:283-7. 
36 Brenner H, Born J, Novak P, et al. Smoking behavior and attitudes towards smoking regulations and passive smoking in the workplace. Prev Med 1997;26: 138-43.

37 McAllister I. Public opinion in Australia on restricting smoking in public places. Tobacco Control 1995:4:30-5.

38 Burden B. Representation versus self-interest in U.S. politics: the cases of tobacco regulation and school choice. Presentation at the Conference of the American Political Science Association; Washington, 2000.

39 Clarke H. The ideological self-perceptions of provincial legislators. Can J Political Science 1978;11:617-33.

40 Elkins D. The perceived structure of the Canadian party systems. Can J Political Science 1974;7:502-24.

41 Flanagan T. Invasion from the right: the Reform Party in the 1993 Canadian election. Papers in political economy: No. 42. London, Ontario: Political Economy Research Group, University of Western Ontario, 1994.

42 Stata Statistical Software: Release 6.0 [program]. College Station, Texas: Stata Corp, 1999
43 Kline R. Principles and practice of structural equation modeling. New York: The Guilford Press, 1998

44 Pederson LL, Bull SB, Ashley M, et al. A population survey on legislative measures to restrict smoking in Ontario: 2. knowledge, attitudes, and predicted behavior. Am J Prev Med 1986;2:316-23.

45 Bacchi CL. Women, policy and politics: the construction of policy problems. London: Sage Publications, 1999.

46 Nathanson CA. Social movements as catalysts for policy change: the case of smoking and guns. Journal of Health Politics, Policy and Law 1999:24:421-88.

47 Christofides N, Chapman S, Dominello A. The new pariahs: discourse on the tobacco industry in the Sydney press, 1993-97. Austr NZ Journa Public Health 1999;23:233-9.

48 Menashe $\mathrm{CL}$, Siegel $\mathrm{M}$. The power of a frame: an analysis of newspaper coverage of tobacco issues - United States, 1985-1996. Journal of Health Communication 1998;3:307-25.

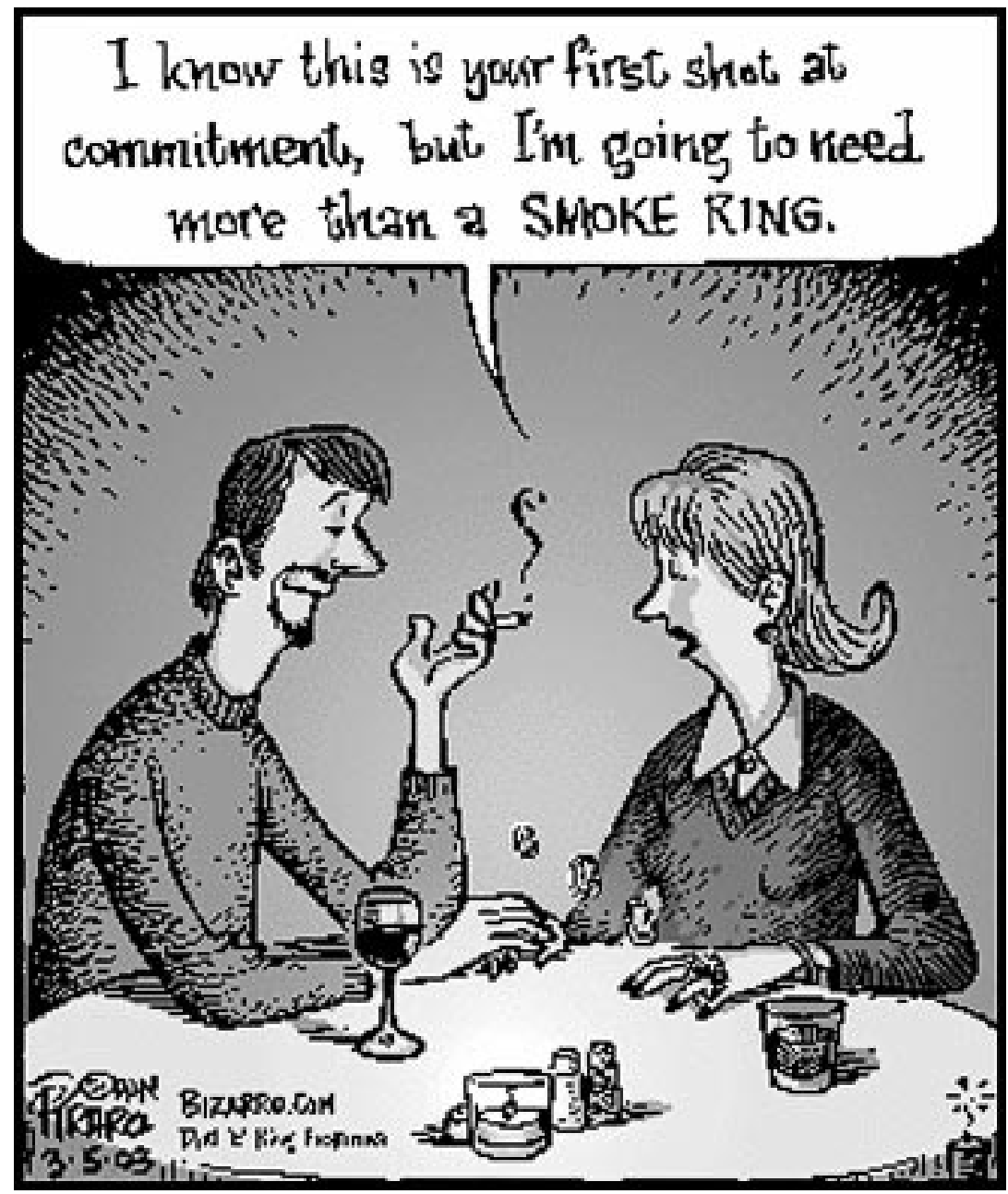

(c) Bizzaro by Dan Piraro. Ucomics. Wednesday, 5 March 2003. 